\title{
Population Development and its Typology in the Czech Republic at the Level of Micro-regions
}

\author{
Miloslav Šašek ${ }^{1 *}$ \\ ${ }^{1}$ Faculty of Social and Economic Studies, J. E. Purkyně University in Ústí nad Labem, \\ Czech Republic \\ *miloslav.sasek@ujep.cz
}

\begin{abstract}
The contribution mainly focuses on monitoring of the population development in the Czech Republic, particularly at the micro-regional level. It monitors development of the natural population change, migration, and overall population development in two monitored periods, and conducts SO ORP typology based on this development with respect to the natural population change, migration, and overall increase. Today, the migration in the developed regions is the determinative element of the population development. To put it simply, the determinative division of the migration population development is into two units (east and west zone, Moravia and Bohemia), where Moravia has negative migration and Bohemia sees positive migration; however, there are significant differences in the middle of the units where Brno metropolitan area has highly positive migration, especially from the rest of Moravia and Silesia, and on the contrary, Karlovy Vary region sees significantly negative migration; over the last years, the negative migration has been relatively higher compared to Moravia-Silesia Region. The micro-regions at SO ORP level assist us in distinguishing of continuous territories with either positive or negative population development.
\end{abstract}

Key words: public administration, migration, population development, Czech Republic

Highlights for public administration, management and planning:

- Differences in the population development at the micro-regional level are shown.

- The results show an increasing regional gap in the population development.

- The connection of population development to public administration reform is discussed.

Received: 7 Jun 2016 - Received in revised form: 20 Sep 2016 - Accepted: 5 Dec 2016

\section{Introduction}

The population migration is a rather complex process conditional on a broad spectrum of effects. Elsewhere in the world, and thereby in the Czech Republic as well, the social and economic conditions influence the character of the migration. According to ( $\mathrm{Hampl}$ et al. 1987), the population migration is the key mechanism of a concentration process. The migration is a structural regional process and therefore, monitoring thereof is tightly related to the regional development and regional policy. The assessment of the spatial structure of the migration processes can legitimately be called as the core of the geographical research of the migration (Hampl 2005). The study of migration has successively become inter-disciplinary (Čermák 2009). In particular, attention is paid to more general problems of the spatial behaviour of the population and root causes or motives of the behaviour (Šašek 2011, 2013).

\section{Methodological notes}

The population development and monitoring thereof is important fur further development chances of the regions. Specifically, the population changes in post-socialist countries, 
such as the Czech Republic encountered delayed effects of global and macroregional population trends, which makes them important issue to be addressed by national and regional policy (Sobotka et al. 2003; Kačírek 2015). These days, the migration is determinative for the regional population increase nationwide. The quantitative increase alone may not always be a plus for further development of the regions, e.g. the migration structures in the 1970s and 1980s in the area of mining districts of former Northern Bohemia Region, where the share of unqualified and low qualified inhabitants, and emigration of university and GCSE graduates resulted in deterioration of the education structure and to a certain extent, it is the phenomena that significantly influences the social micro-climate in this region now as well (Šašek 2011). The contribution tries to review and analyze the population development in the Czech Republic particularly at the micro-level, and to demonstrate the impact of the migration on the natural change of the micro-regions having positive migration development since mid of the 1990s. The contribution is based on comparison analysis of the development trends as well as the typology of the micro-regional at the SO ORP level by migration, natural, and total population increase. The typology has been made based on comparison of the population development in two periods of time, namely 2004-2007 and 2008-2011. There are five types selected for each population development component into which each SOP ORP is included.

Table 1 - Typology of SO ORP by migration behaviour of inhabitants in 2004-2007 and 2008-2011 (source: Inhabitants migration database, Čsú 2012, own calculations)

\begin{tabular}{lrrrrrr} 
& SO ORP type & & & & & \\
\cline { 2 - 5 } Region & $\mathbf{1}$ & $\mathbf{2}$ & $\mathbf{3}$ & $\mathbf{4}$ & $\mathbf{5}$ & ORP total \\
\hline Prague & 1 & 0 & 0 & 0 & 0 & 1 \\
Central Bohemia Region & 17 & 6 & 3 & 0 & 0 & 26 \\
Southern Bohemia Region & 1 & 3 & 6 & 4 & 3 & 17 \\
Plzeň Region & 5 & 2 & 7 & 1 & 0 & 15 \\
Karlovy Vary Region & 0 & 1 & 2 & 2 & 2 & 7 \\
Ústí Region & 3 & 6 & 6 & 1 & 0 & 16 \\
Liberec Region & 2 & 1 & 3 & 1 & 3 & 10 \\
Hradec Králové Region & 1 & 1 & 4 & 6 & 3 & 15 \\
Pardubice Region & 3 & 1 & 4 & 2 & 5 & 15 \\
Vysočina Region & 0 & 1 & 2 & 7 & 5 & 15 \\
Southern Moravia Region & 6 & 2 & 8 & 2 & 3 & 21 \\
Olomouc Region & 0 & 0 & 3 & 3 & 7 & 13 \\
Zlín Region & 0 & 0 & 4 & 3 & 6 & 13 \\
Moravia-Silesia Region & 1 & 0 & 6 & 3 & 12 & 22 \\
Total & 37 & 21 & 58 & 40 & 50 & 206
\end{tabular}




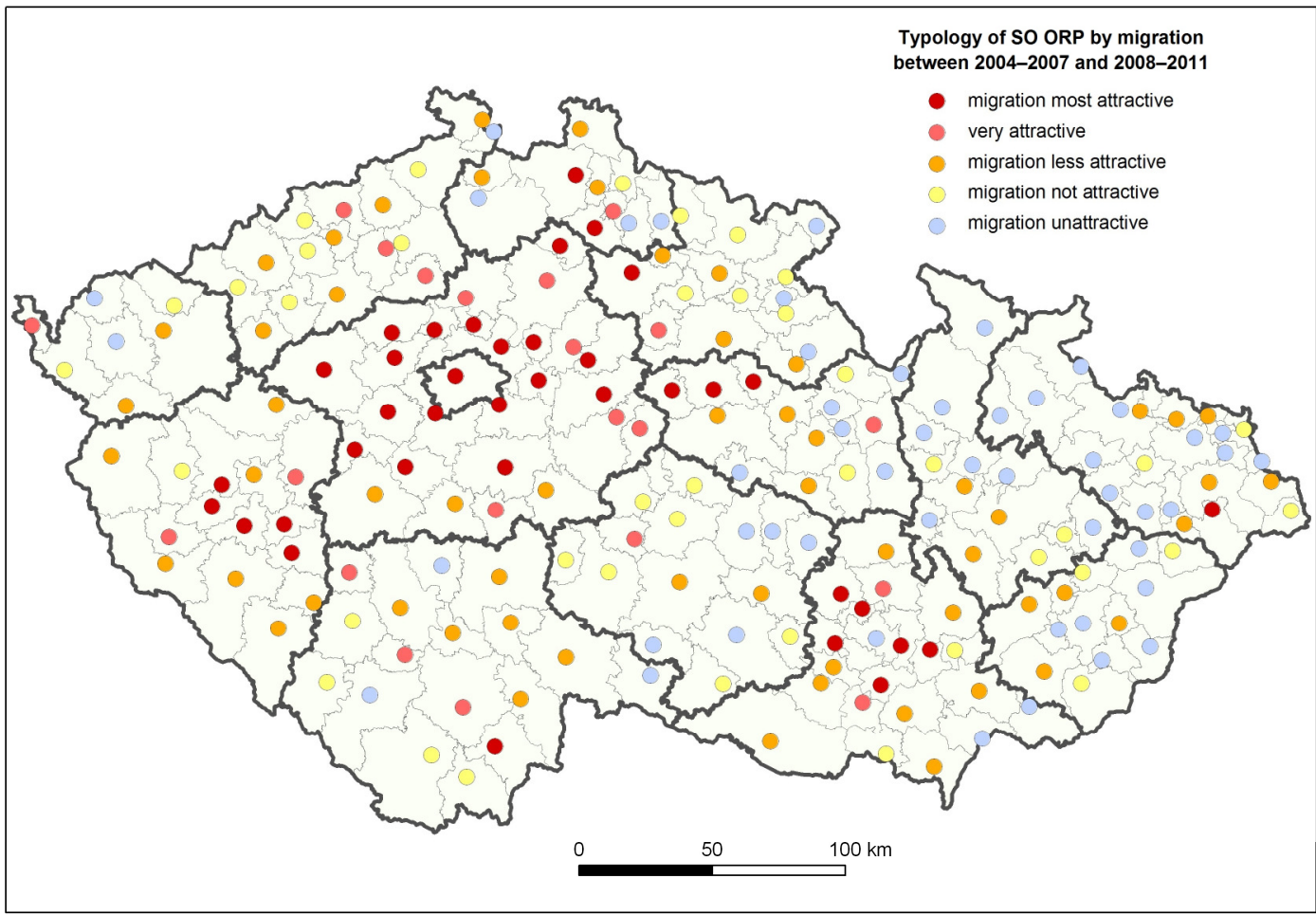

Fig. 1 - Typology of SO ORP by migration between 2004-2007 and 2008-2011 (ČSÚ, own processing)

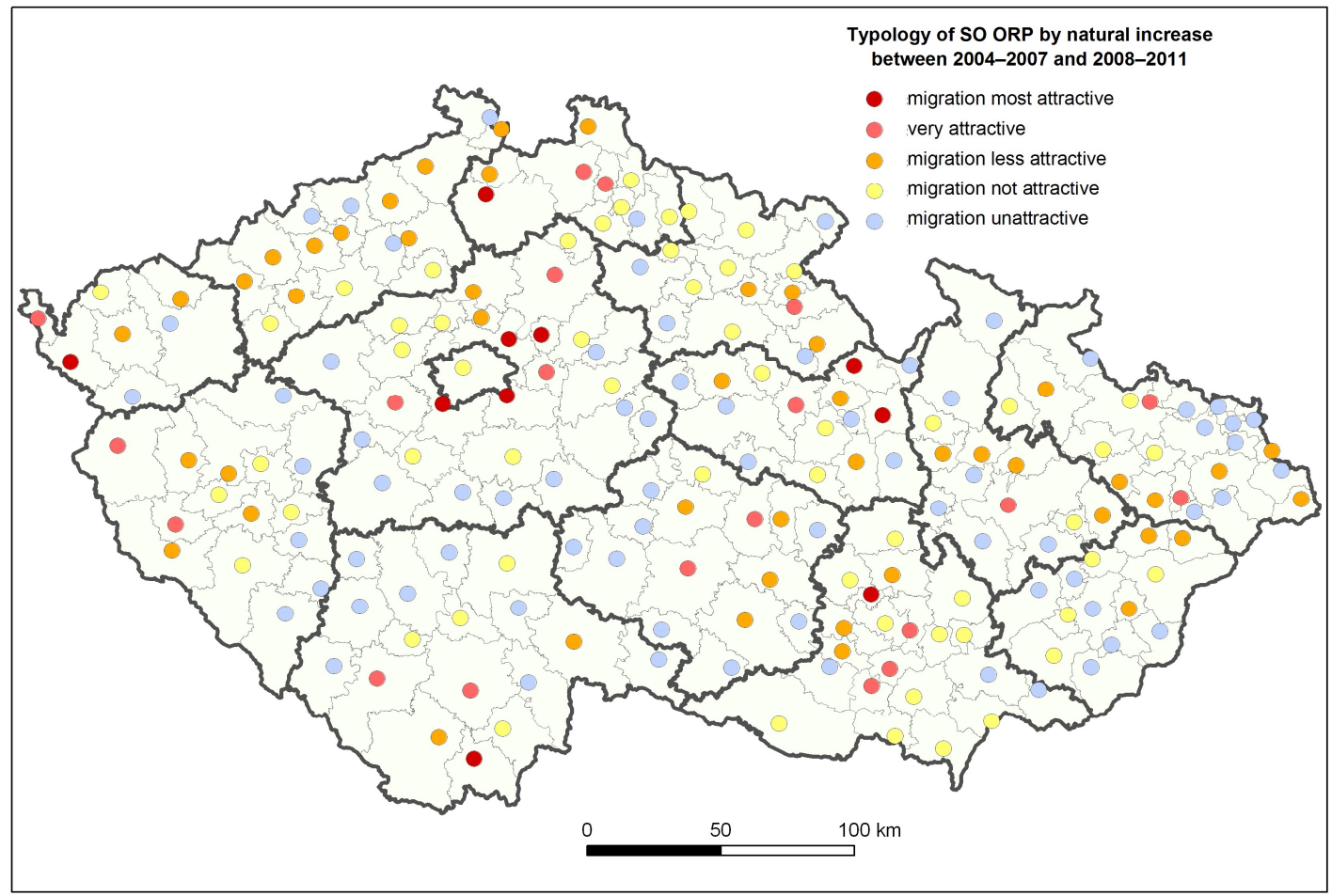

Fig. 2 - Typology of SO ORP by natural increase between 2004-2007 and 2008-2011 (Čsú, own processing) 
3. Results: the public administration reform, micro-regions, and population development

When looking at the territory at the different regional level we found out that the differentiation increases with lower regional level. Monitoring of the population development at the micro-level is related to the reform of the territorial public administration late in 2002. Following the district authorities were abolished within the second phase of the reform of the territorial public administration, Act No. $314 / 2002$ Coll. defined the municipalities with a delegated municipal competence and the municipalities with extended competences effectively from 1 January 2003. Roughly $80 \%$ of their competence is covered by 205 municipalities with extended competences. Owing to the reform we can monitor the microregions that correspond to the administrative districts of the municipalities with extended competences (defined by Decree of the Ministry of Interior No. 388/2002 Coll. dated 15 August 2002, effective from 1 January 2003). The 205 SO ORP micro-regions largely equal to the territory of the districts existing from 1960.

Based on the migration behaviour of inhabitants between 2004-2007 and 2008-2011 (Table 1, Fig. $1)$, the SO ORP typology has been made where five types were defined. The first type is the migration most attractive SO ORP and this type includes the units with annual average migration balance exceeding 0.50 per mil or more in both periods in question; the second type of very attractive SO ORP includes the territorial units with migration balance over 0.50 in one of the periods in question and positive, but with lower value, in the other period in question. The third type (migration less attractive) of SO ORP includes the territorial units with positive migration balance under 0.50 per mill in both periods in question. The fourth type (migration not attractive) of SO ORP includes the units with one negative and one positive migration balance in either of the periods in question. The fifth type (migration unattractive) of SO ORP includes the territorial units reporting negative balances in both periods in question.
The third type covers the most of the territorial units (58 units). The number of the units with negative values in both periods in question, i.e. the fifth type, is high as well. The first two types include 58 units, i.e. almost $30 \%$ of SO ORP has achieved rather high migration balance for the periods in question. A higher share thereof (37, i.e. $18 \%$ of total SO ORPs) falls into the migration most attractive units. Almost one half of the migration most attractive units belong to the closest neighbourhood of Prague (17 in Central Bohemia Region); significant concentration of this SO ORP type can also be seen in the metropolitan areas of Brno (6 units) and Plzeň (5 units). Over three quarters of the migration most attractive units comes under the metropolitan areas of three of four biggest Czech cities. With strong links to Prague and Central Bohemia area we can see six migration most attractive SO ORPs, in particular 3 in Pardubice Region along Pardubice - Prague railway, then Liberec and Turnov linking to highway to Prague, and Jičín in Hradec Králové Region being linked with Prague properly as well. Far from said metropolitan areas there is the one and only migration most attractive unit Frýdlant nad Ostravicí - the phenomena of Čeladná location where there is the space for quality living in quality environment for the Ostrava metropolitan area.

Prague being the specific SO ORP unit is the migration most attractive territory in the Czech Republic. It records the second best migration balance following Central Bohemia Region. Over the eight-year period (2004-2011), the migration increase has reached 91,814 inhabitants, which makes average annual balance of 0.95 per mil. Central Bohemia Region is the only region of thirteen remaining territorial units in the Czech Republic with all SO ORPs in positive migration balance in both periods in question. The determinative share (17 units) of SO ORPs comes under the migration most attractive (first type), six units fall into the second type, and three units fall into third type. Significant difference in SO ORPs by individual types of the migration behaviour can be found between Bohemia and Moravia as the territorial units. Of 37 SO ORPs belonging to the first type, only 7 is located in 
Moravia (as mentioned above, 6 units in the Brno metropolitan area and Frýdlant nad Ostravicí Čeladná). Of 21 SO ORPs belonging to the second type only two units are located in Moravia (in Southern Moravia Region). On the contrary, of 50 SO ORPs of the fifth type, 34 can be found in Moravia. Olomouc and Zlín Regions do not have any SO ORP in the first and second type and in line with this, one half of total SO ORPs of these regions comes under the fifth type. No SO ORP of the first type can be found in Vysočina and Karlovy Vary Regions. No SO ORP in Plzeň and Ústí Regions falls into the fifth type in addition to Prague and Central Bohemia Regions.

The SO ORP typology with definition of five types was made based on the development of natural change over the monitored periods of time (Table 2, Fig. 2). The first type is the significant natural increase and this type includes the units with annual average natural increase reaches 0.20 per mil or more in both periods in question; the second type of relatively significant natural increase includes the territorial units with the natural increase of 0.20 in one of the periods in question and positive, but with lower value, in the other period in question. The third type (low natural increase) includes the territorial units with positive natural increase but under 0.20 per mill in both periods in question; the fourth type (insignificant natural increase) includes the units with one natural increase and one natural decrease in either of the periods in question. The fifth type (population decrease) of SO ORP includes the territorial units reporting negative natural change in both periods in question.

Table 2 - The typology of SO ORP by natural increase of inhabitants in the periods 2004-2007 and 2008-2011 (source: Inhabitants migration database, Čsú 2012, own calculations)

\section{Typ SO ORP}

\begin{tabular}{|c|c|c|c|c|c|c|}
\hline \multirow[b]{2}{*}{ kraj } & & \multirow[b]{2}{*}{ celkem ORP } \\
\hline & 1 & 2 & 3 & 4 & 5 & \\
\hline Praha & 0 & 0 & 0 & 1 & 0 & 1 \\
\hline Středočeský & 4 & 3 & 2 & 8 & 9 & 26 \\
\hline Jihočeský & 1 & 2 & 2 & 4 & 8 & 17 \\
\hline Plzeňský & 0 & 2 & 4 & 4 & 5 & 15 \\
\hline Karlovarský & 1 & 1 & 2 & 1 & 2 & 7 \\
\hline Ústecký & 0 & 0 & 9 & 3 & 4 & 16 \\
\hline Liberecký & 1 & 2 & 2 & 4 & 1 & 10 \\
\hline Královéhradecký & 0 & 1 & 3 & 7 & 4 & 15 \\
\hline Pardubický & 2 & 1 & 3 & 3 & 6 & 15 \\
\hline Vysočina & 0 & 2 & 4 & 1 & 8 & 15 \\
\hline Jihomoravský & 1 & 3 & 3 & 11 & 3 & 21 \\
\hline Olomoucký & 0 & 1 & 4 & 2 & 6 & 13 \\
\hline Zlínský & 0 & 0 & 3 & 4 & 6 & 13 \\
\hline Moravskoslezský & 0 & 2 & 6 & 4 & 10 & 22 \\
\hline celkem & 10 & 20 & 47 & 57 & 72 & 206 \\
\hline
\end{tabular}




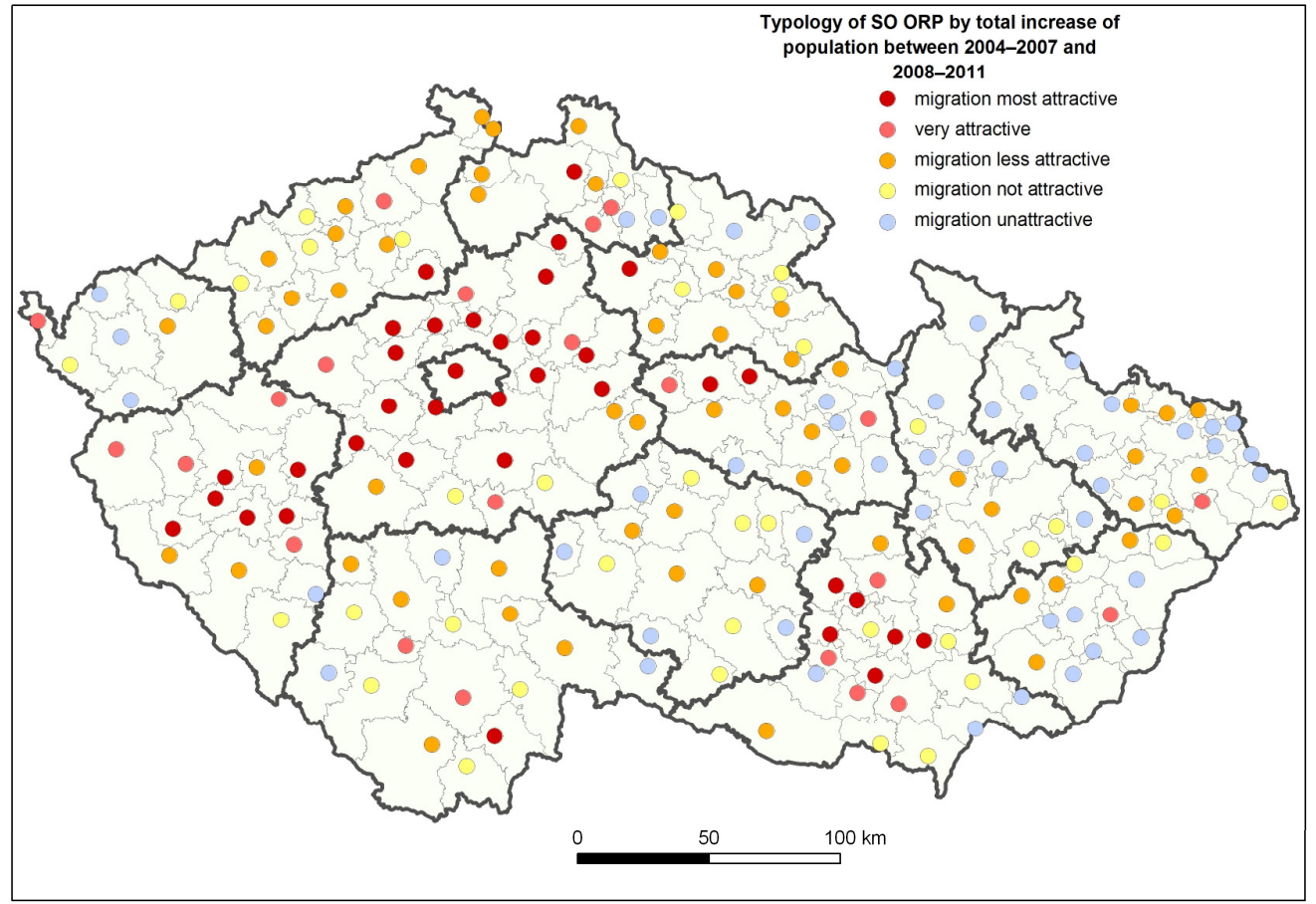

Fig. 3 - Typology of SO ORP by total increase between 2004-2007 and 2008-2011 (ČSú, own processing)

Table 3 - The typology of SO ORP by total increase of inhabitants in the periods 2004-2007 and 2008-2011 (source: Inhabitants migration database, Čsú 2012, own calculations)

Typ SO ORP

\begin{tabular}{|c|c|c|c|c|c|c|}
\hline kraj & 1 & 2 & 3 & 4 & 5 & celkem ORP \\
\hline Praha & 0 & 0 & 0 & 1 & 0 & 1 \\
\hline Středočeský & 4 & 3 & 2 & 8 & 9 & 26 \\
\hline Jihočeský & 1 & 2 & 2 & 4 & 8 & 17 \\
\hline Plzeňský & 0 & 2 & 4 & 4 & 5 & 15 \\
\hline Karlovarský & 1 & 1 & 2 & 1 & 2 & 7 \\
\hline Ústecký & 0 & 0 & 9 & 3 & 4 & 16 \\
\hline Liberecký & 1 & 2 & 2 & 4 & 1 & 10 \\
\hline Královéhradecký & 0 & 1 & 3 & 7 & 4 & 15 \\
\hline Pardubický & 2 & 1 & 3 & 3 & 6 & 15 \\
\hline Vysočina & 0 & 2 & 4 & 1 & 8 & 15 \\
\hline Jihomoravský & 1 & 3 & 3 & 11 & 3 & 21 \\
\hline Olomoucký & 0 & 1 & 4 & 2 & 6 & 13 \\
\hline Zlínský & 0 & 0 & 3 & 4 & 6 & 13 \\
\hline Moravskoslezský & 0 & 2 & 6 & 4 & 10 & 22 \\
\hline celkem & 10 & 20 & 47 & 57 & 72 & 206 \\
\hline
\end{tabular}


According to total increase of inhabitants in 2004-2007 and 2008-2011 (Table 3, Fig. 3), the typology of SO ORP was made. Five types were defined. The first type is the significant population increasing SO ORPs and this type includes the units with annual average natural increase reaching 0.50 per mil or more in both periods in question; the second type of relatively significant population increasing SO ORPs includes the territorial units with the total increase of 0.50 in one of the periods in question and positive, but with lower increase, in the other period in question. The third type (slight population increase) includes the territorial units with positive total increase but under 0.50 per mill in both periods in question; the fourth type (insignificant population increase) includes the units with one total population increase and one total decrease in either of the periods in question. The fifth type (population decrease SO ORPs) includes the territorial units reporting negative natural increase in both periods in question.

When comparing the migration development and natural change we can see that the number of units with adverse development in the natural change is much higher than the units with negative migration development. The total population development inevitably corresponds more with the migration development because the migration increase values are much higher, which confirms that the migration has a determinative impact on the population development of the regions in the developed countries (Čermák et al. 2009). This is demonstrated by almost identical number of the SO ORP units in each type by the migration and total increase.

All mentioned above is supported by increasing gap between east and west, where only Brno is an exception in the Moravian social and economic, and therefore population development (Šašek 2016).

When looking at 37 migration most attractive SO ORPs you can see that of total number of units, 15 and 22 units had the migration balance higher and lower, respectively. Prague has lower balance; it is defined as the only of the units and no further analyses are possible. Central Bohemia Region, which has the highest number of the units of this type (17), reports higher migration balance in 9 of them in the second monitored period, and 8 units report the lower balance. This corresponds to the fact Central Bohemia Region as the only one had higher migration balance in the second monitored period than in the first one, and of the second type units 4 of 6 units in Central Bohemia Region had higher balance in the second period, as well as 2 of 3 for the third type units. In Plzeň Region, only one of five SO ORPs belonging to the first type showed higher balance in the second period, and in Southern Moravia Region, 2 units of 6 showed the same. Of the remaining SO ORPs belonging to the most attractive type, 3 and 5 had the migration balance higher and lower, respectively.

When comparing SO ORP where the district towns of Central Bohemia Region are located we can see that 6 falls into the first type, 4 falls into the second type, and 2 falls into third type of SO ORP by the migration attractiveness. The 4 units belonging to the first type seen the increased migration balance over time, one SO ORP showed decrease, and one showed stagnation. For both remaining types, the balance increased in half of the units, and decreased in the other half (Prague-východ and Prague-west districts have their seats in Prague).

When monitoring SO ORP where regional cities are located, of 13 units (Central Bohemia Region's authority is located in Prague), 3 only belongs to the first type (Prague, Liberec, and Pardubice), České Budějovice fall into type 2, 6 SO ORPs fall into type three (Plzeň, Karlovy Vary, Ústí nad Labem, Hradec Králové, Jihlava, Olomouc), and thee to type five (Brno, Zlín, Ostrava). For six of 13 monitored SO ORPs the migration balance increased; 7 reported migration decrease. Position of Brno as the hub of an important metropolitan area is quite interesting here. SO ORP Brno has negative migration balance in both periods (type five), 
whereas Prague has high positive migration balance in both periods (type one), Plzeň has positive balance in both periods (type three). To a certain extent we could attribute the results to prices of flats that did not correspond to reality in Brno (identical price levels as in Prague). On the other hand, there were quite sufficient number of plots near SO ORP Brno for at relatively affordable prices, and delay of faster suburbanization growth compared to Prague by 5 years in average.

The type 4 includes SO ORPs having positive and negative migration balances in both periods of time, and in total there are 40 units like this. Thirty three of them reported positive migration balance between 2004 and 2007 and 7 units in the second period. The migration balance "improvement" ranges from 0.03 per mil of annual diameter (Světlá nad Sázavou) up to 0.25 for Most. The most frequent interpretation relates to massive requalification events, construction of the industrial zones with tax holidays for the investors, and cheap provision of lands or providing the lands for free (Žatec, Most, Jablunkov). The question is the amount of costs for creation of one job position; according to authors from FSE UJEP Ústí nad Labem (Hladík \& Hlaváček 2013), total costs amounted to CZK 2 million for single job position in the Triangle Zone, and the costs are fairly high. An interesting change to the migration behaviour can be seen in Náměšt' nad Oslavou to where a helicopter base of the Czech Armed Forces was relocated, and relocation of the employees including their families resulted in change to positive migration balance from the negative one (annual average 0.09 per mill of the change compared to previous period by 0.15 per mil).

The migration activity is significantly associated with the traffic connection with a centre and geographical interconnection. This is a typical for three SO ORPs in Pardubice Region that comes under the type one (Pardubice, Přelouč, Holice) from where daily commuting to Prague is seamless. Owing to the main railway corridor and availability of the D8 highway, SO ORP Roudnice nad Labem is attractive with the highest positive balance of all SO ORPs of Ústí Region in both periods. In addition, annual average of the migration balance for the 8-year period in question, it overtakes several SO ORPs falling into the first type. Roudnice is in the second type because the annual average balance dropped under 0.7 per mill in the second period.

On the other hand we can, however, see significant negative balances of many SO ORPs along or close to the east-west railway where the weekly commuting to Prague and Central Bohemia increased due to poor social and economic situation, and where younger and more qualified part of the commuters exchanged with change to residence over time (Ústí nad Orlicí, Česká Třebová, Moravská Třebová, Hranice, Přerov).

\section{Discussion and conclusions}

The migration development has significantly influenced structure of inhabitants of each region not only at the micro-regional level but also at the district and regional level as well (Populační vývoj ČR 2007). The structures of the migrants are considerably younger and more educated than population average of the Czech Republic and regions. The development over last about 20 years including the period 2004-2011 in question has significantly changed structures of the population both migration-active SO ORP, districts, regions as well as de-population units.

Rejuvenation could be seen in the migrationattractive SO ORP and on the other hand, less and migration-unattractive SO ORPs report ageing. Total values for the regions and districts support that. E.g. drop in the average age of Prague-západ and Prague-východ districts inhabitants between census in 2001 and 2011 by about 1 year and only half-year increased average age of Prague population, whereas average age of citizens of the Czech Republic increased by 0.9 during the same period. Prague-východ and Prague-západ districts have the highest share of child component of all districts of the Czech Republic (almost $4 \%$ higher than Czech average), Central Bohemia Region has $1.2 \%+$ over the Czech average (Populační vývoj ČR 2008).

The migration also significantly influenced the education structure of SO ORP in the background of Prague. In the period between census in 1991 
and 2011, the number of university graduates in Prague grew from $16 \%$ to $20.7 \%$, in Prague-západ from $6.9 \%$ to $17 \%$, and in Prague-východ from $4.6 \%$ to $13.6 \%$ (Šašek 2013).

\section{References}

Čermák Z, Hampl M, Müller J (2009) Současné tendence vývoje obyvatelstva metropolitních areálủ v Česku: Dochází k významnému obratu? Geografie sborník České geografické společnosti 114(1): 37-54.

Hampl M (2005) Geografická organizace společnosti v České republice: transformační procesy a jejich obecný kontext. Př́rodovědecká fakulta Univerzity Karlovy, katedra sociální geografie a regionálního rozvoje, Praha.

Hampl M, Gardavský V, Kühnl K (1987) Regionální struktura a vývoj systému osídlení ČSR, UK, Praha.

Hladík R, Hlaváček P (2013) Development processes in the Ústí region and the contribution of industrial zones for the region. UJEP, Ústí nad Labem.

Kačírek P (2015) Demographic ageing in the old industrial regions - specifics and links on the example of the Ústí nad Labem Region (N Czechia). GeoScape 9(1): 24-32.

Katedra demografie a geodemografie PřF UK (2007) Populační vývoj České republiky 2001 - 2006. UK Praha.

Katedra demografie a geodemografie PřF UK (2008) Populační vývoj České republiky 2007. UK, Praha.

Šašek M (2011) The Changes of Internal Migration in the Czech Republic (with the Focus on Analysis of the Changes in Ústí nad Labem Region). AUP Studia Oeconomica 164, UJEP, Ústí nad Labem.

Šašek M (2013) Migrace obyvatelstva v České republice a regionální rozvoj. UJEP, Ústí nad Labem.

Šašek M (2016) Population and Socioeconomic Development in the Czech Republic at Micro-regional Level in the 2008 - 2013 Crisis Years. UJEP, Ústí nad Labem.

Sobotka T, Zeman K, Kantorová V (2003) Demographic Shifts in the Czech Republic after 1989: A Second Demographic Transition View. European Journal of Population / Revue européenne de Démographie 19(3): 249-277. 